\title{
Forecasting Analysis on the Impact of Pandemic Towards Cigarette Sales
}

\author{
Siti Holifahtus Sakdiyah*, Nurafni Eltivia, Nur Indah Riwajanti, Kurnia Ekasari \\ Accounting Department \\ State Polytechnic of Malang \\ Malang, Indonesia \\ *shefaa_love13@yahoo.co.id
}

\begin{abstract}
The purpose of this study is to analyze sales using moving average forecasting. The method used is a quantitative method with primary data on actual sales results and forecast calculations using the moving average method. The results of this study are sales with moving average forecasting after the pandemic has increased. In contrast to the situation that actually occurs in a company where with a pandemic, sales have decreased. This difference will be the company's consideration in determining the policies that will be enforced in the company. Although forecasting results cannot be used as a benchmark for the actual situation, forecasting is useful in making decisions, so that in the next period it can determine sales planning.
\end{abstract}

Keywords-forecasting, moving average, pandemic, sales results

\section{INTRODUCTION}

Cigarette company by the name Gagak Hitam was founded Mr. Nawar H. Wasil and located in Bondowoso Regency, is a local cigarette factory that produces hand-rolled cigarettes with two brands, namely Gagak Hitam Kuning Istimewa and Gagak Hitam Gold, and cigarettes filters with Gagak Hitam Filter brand. This company was founded in 2004 and officially started operations in 2005. During the period between 2005 and 2020, there were many increases and decreases in sales due to internal and external factors.

2016-2019 were difficult times for the company because, in 2016 - 2018, there were a lot of illegal cigarettes circulating [1] and the company owner health condition decreased. In 2019 the owner of the company passed away. This affects sales because the management, which plays a vital role in the office, is the son of the company's owner and due to the psychological effect of losing his father figure, affects performance in the company. At the beginning of 2020, the management tried to get back up after a mourning period but was deemed sufficient. There's been a significant overhaul in management. Starting from employee rotation and adding a new management team.

When the company wants to rise, in 2020, Indonesia and the whole world was hit by a pandemic. Of course, this affects the company's condition, which is still unstable after the owner's death. Even though there is no company quarantine period, where the company during the pandemic is still operating, the health protocol that the company must implement affects the production department. For the handheld kretek cigarette production section, all workers who originally sat close together must be spaced \pm 1 meter apart. This affects the number of workers in the production department. Decreasing workers due to the pandemic's effects resulted in reduced cigarette production and decreased sales results. To overcome this problem, the company increases working hours and overtime workers on holidays.

Companies in making decisions to increase or decrease production are deemed necessary to forecast sales. Forecasting is an attempt by a company to make future sales predictions by looking at sales data from the past. This method of predicting the company is significant for every division. For example, if in forecasting it is known that extensive sales results which require many production results, it will affect the HRD department in increasing the production workforce, the finance section in the labor cost budget and the budget for purchasing raw material supplies, the marketing department with methods or marketing support programs.

In forecasting, using the moving average method must have complete data. Not all data can be used for this forecasting approach [2]. Forecasting using the moving average method for 2,3, and 4 months has the least error [3]. Forecasting can be used to predict not only sales but can also be used to indicate the number of tourists [4], agricultural commodity forecasting [5], capital market [6], and can be used as a tool to compare the number of passengers [7].

Forecasting is an estimation process carried out in the present to predict what will happen in the future with data from the past [8]. Estimation aims to minimize the risk of mistakes that the company will make in making future decisions. Making forecasts is not easy, especially for good forecasting. This is because predicting does not provide a definite answer for every event in the future, but forecasting only provides an overview of future events so that they can make the best decisions. 
Currently, forecasting covers various fields, including government, medical, socio-politics, finance, economy, and industrial business. In all areas, forecasting is an important thing to do. For example, in the industrial business sector, especially the manufacturing business, all divisions are related. If one division experiences a disturbance, it will result in other divisions. In the manufacturing business, forecasting should be a mandatory thing for companies [9] because, from this forecast, each division will make important decisions regarding its division's sustainability. In the production section of forecasting, it is essential to make a budget for raw materials, a budget for supporting materials, an inventory budget for dealing with the risk of late delivery, a budget for labor, and a budget for production needs. In the financial division, forecasting is used to predict the revenue and expenses required for the coming period [10]. This is important because companies can make decisions for cost efficiency or add to the budget they feel is lacking by looking at cost forecasting. For the marketing division, forecasting can predict sales to provide information to the finance and production divisions [11].

In education, forecasting is also used to predict future research directions [12], using neural networks [13] and is used to update insights and knowledge [14]. Forecasting has also made progress in Gardner research [15] and how is it different from forecasting each time series [16]. Forecasting can be used to predict the incomprehensible heterogeneity between individuals [17].

Sales forecasting can be an essential factor in a company's business plan [18]. This sales level forecasting is the company's expectations that must be achieved and based on past data. Sales forecasting information is vital to the finance division because sales are a source of funds. This information is essential for the production division to make a production budget that must be made [19]. In making a sales forecast, there are several ways you can do it. First, forecasting is based on the opinions of company leaders. Each leader of the branch office can determine his own sales forecast. Second, by surveying company salespeople who are directly related to consumers. Third, predict using direct surveys of buyers without intermediaries from salespeople. And the last way is the statistical method, where statistical science has provided various methods of forecasting. Among the four methods, it is the statistical method that will be used in this research.

The quantitative statistical method is a method of forecasting using data from the past with a pattern of changing data from time to time without considering other variables' influence [20]. There are several methods in statistical quantitative forecasting. First, the moving average method (moving average). This forecasting by taking observational data, looking for the standard, and the average is projected into future forecasts. Second, the Exponential Smoothing method. Third, the decomposition method, which is performed on data with the same pattern, will be repeated.
In this study, forecasting using the moving average method is used. The moving average method uses several actual data from past data to create forecasting data in the future. The moving average method has the characteristic of requiring historical data for a certain period. The longer the moving average, the smoother the moving average will be.

This study analyzes forecasting using the moving average method to predict the number of cigarette sales in the Gagak Hitam cigarette company in 2021 after going through the pandemic period based on sales data from 2005 to 2020 .

\section{RESEARCH METHODS}

This study uses quantitative methods with the object of research is the Gagak Hitam cigarette company. The focus of the data that will be used as research is data on cigarette sales. During the 2020 period, the company experienced a pandemic's impact so that forecasts for 2021 can be used as a benchmark for companies in making decisions.

The data needed is data on cigarette sales from 2005 - 2020 with the primary data source, namely direct data collection to the Gagak Hitam cigarette company without intermediaries. Data retrieval uses the documentation method where data or records already exist for further study and processing.

To calculate moving average forecasting, this study uses the excel application. The moving average method is a method whose forecasting level is close to what will happen because it uses the average value of the company's actual data. [21]:

To calculate the moving average method using the formula

$$
\mathrm{Ft}+1=\left(\mathrm{Y}^{\prime \prime} \mathrm{t}+\mathrm{Yt}-1+\mathrm{Yt}-2 \ldots+\mathrm{Yt}-\mathrm{n}+1\right) / \mathrm{n}
$$

Where :

$$
\begin{aligned}
& \mathrm{Ft}+1=\text { Forecast for the period } \mathrm{t}+1 \\
& \mathrm{Yt}=\text { real value for period } \mathrm{t} \\
& \mathrm{n}=\text { Duration of the moving average }
\end{aligned}
$$

the value of $\mathrm{n}$ is the number of periods on the moving average

\section{RESULTS AND DISCUSSION}

Sales data from 2005 - 2020 are obtained from companies shown in Table 1 are primary data processed in this study. To facilitate the study, researchers used the quarterly sales data. Figure 1 shows a graph of cigarette sales for $2005-2020$.

This study uses Moving Average 4 because there are some incomplete 1-year data to facilitate data processing using moving average calculations with an average of the last 4 data. The average with the previous 4 data still does not show a result close to the actual data. Therefore, the average is averaged again so that it is more relative to the real data. Furthermore, this research also considers the seasonal factor's 
existence and how to eliminate the seasonal factor by calculating the standard deviation.

TABLE I. CigARETTE SALES DATA F OR $2005-2020$

\begin{tabular}{|l|l|l|l|l|}
\hline Year & Quarter 1 & Quarter 2 & Quarter 3 & Quarter 4 \\
\hline 2005 & - & 158.050 & 94.000 & 338.508 \\
\hline 2006 & 911.670 & 840.855 & 560.274 & 635.026 \\
\hline 2007 & 602.471 & 1.692 .159 & 2.118 .941 & 2.592 .192 \\
\hline 2008 & 2.513 .656 & 2.807 .348 & 3.547 .897 & 3.075 .682 \\
\hline 2009 & 3.008 .861 & 2.934 .251 & 3.009 .291 & 3.829 .322 \\
\hline 2010 & 2.530 .955 & 2.811 .318 & 2.360 .689 & 3.474 .057 \\
\hline 2011 & 1.995 .208 & 2.945 .830 & 1.995 .053 & 1.526 .780 \\
\hline 2012 & 1.290 .070 & 1.286 .262 & 1.998 .245 & 2.830 .850 \\
\hline 2013 & 1.949 .166 & 1.481 .924 & 1.105 .695 & 1.221 .380 \\
\hline 2014 & 1.218 .072 & 1.343 .672 & 1.307 .750 & 1.380 .925 \\
\hline 2015 & 1.048 .271 & 1.164 .013 & 1.309 .983 & 1.380 .746 \\
\hline 2016 & 1.133 .148 & 1.358 .464 & 1.398 .894 & 1.524 .930 \\
\hline 2017 & 1.323 .111 & 1.342 .830 & 1.115 .784 & 1.191 .442 \\
\hline 2018 & 830.323 & 688.486 & 697.941 & 784.291 \\
\hline 2019 & 626.602 & 526.487 & 454.021 & 470.374 \\
\hline 2020 & 323.571 & 144.500 & 191.250 & - \\
\hline
\end{tabular}

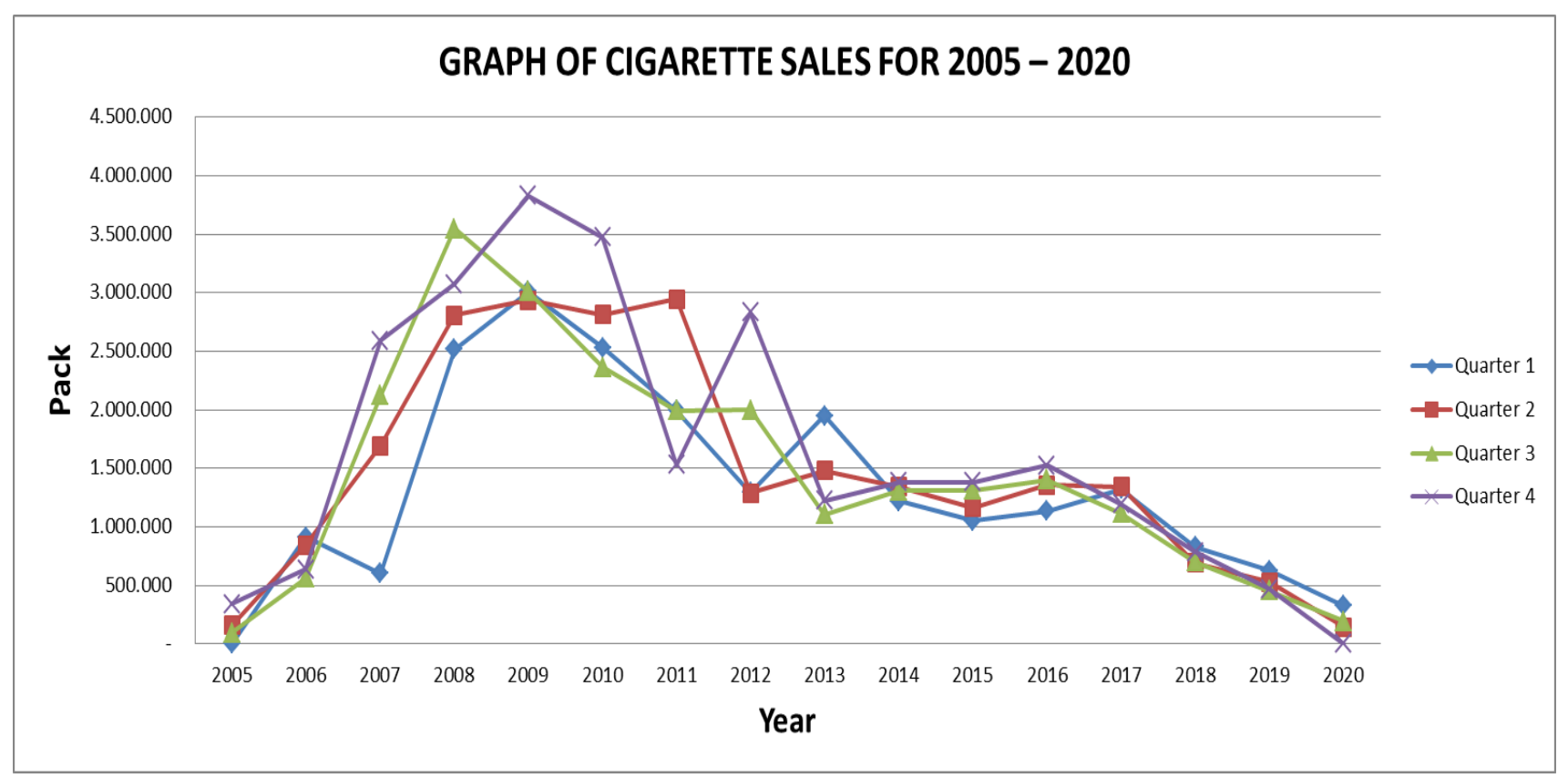

Fig. 1. Graph of cigarette sales for $2005-2020$. 


\begin{tabular}{|c|c|c|c|c|c|c|c|c|c|c|}
\hline Year & Quarter & Sales & $\begin{array}{l}\text { Moving } \\
\text { Average }\end{array}$ & $\begin{array}{c}\text { Center } \\
\text { Moving } \\
\text { Average }\end{array}$ & $\begin{array}{l}\text { Seas onallity } \\
\text { ( St ) } \\
\text { Irregularity }\end{array}$ & Seasonalillity & $\begin{array}{c}\text { Deseas ona } \\
\text { lillity }\end{array}$ & $\mathbf{t}$ & Trend & Forecasting \\
\hline \multirow{4}{*}{2005} & Q1 & - & & & & 1.566 .742 & - & 1 & 1,42705 & 2.235 .814 \\
\hline & $\mathrm{Q} 2$ & 158.050 & & & & 1.549 .535 & 0,10200 & 2 & 1,41327 & 2.189 .913 \\
\hline & $\mathrm{Q} 3$ & 94.000 & & - & & 1.551 .732 & 0,06058 & 3 & 1,39950 & 2.171 .642 \\
\hline & $\mathrm{Q} 4$ & 338.508 & 375.557 & 375.557 & 0,90135 & 1.566 .968 & 0,21603 & 4 & 1,38572 & 2.171 .378 \\
\hline \multirow{4}{*}{2006} & $\mathrm{Q} 1$ & 911.670 & 546.258 & 546.258 & 1,66894 & 1.566 .742 & 0,58189 & 5 & 1,37194 & 2.149 .482 \\
\hline & Q2 & 840.855 & 662.827 & 662.827 & 1,26859 & 1.549 .535 & 0,54265 & 6 & 1,35817 & 2.104 .529 \\
\hline & $\mathrm{Q} 3$ & 560.274 & 736.956 & 736.956 & 0,76025 & 1.551 .732 & 0,36106 & 7 & 1,34439 & 2.086 .138 \\
\hline & $\mathrm{Q} 4$ & 635.026 & 659.657 & 659.657 & 0,96266 & 1.566 .968 & 0,40526 & 8 & 1,33062 & 2.085 .034 \\
\hline \multirow{4}{*}{2007} & Q1 & 602.471 & 872.483 & 872.483 & 0,69053 & 1.566 .742 & 0,38454 & 9 & 1,31684 & 2.063 .150 \\
\hline & $\mathrm{Q} 2$ & 1.692 .159 & 1.262 .149 & 1.262 .149 & 1,34070 & 1.549 .535 & 1,09204 & 10 & 1,30307 & 2.019 .145 \\
\hline & Q3 & 2.118 .941 & 1.751 .441 & 1.751 .441 & 1,20983 & 1.551 .732 & 1,36553 & 11 & 1,28929 & 2.000 .633 \\
\hline & $\mathrm{Q} 4$ & 2.592 .192 & 2.229 .237 & 2.229 .237 & 1,16282 & 1.566 .968 & 1,65427 & 12 & 1,27551 & 1.998 .690 \\
\hline \multirow{4}{*}{2008} & Q1 & 2.513 .656 & 2.508 .034 & 2.508 .034 & 1,00224 & 1.566 .742 & 1,60438 & 13 & 1,26174 & 1.976 .819 \\
\hline & Q2 & 2.807 .348 & 2.865 .273 & 2.865 .273 & 0,97978 & 1.549 .535 & 1,81174 & 14 & 1,24796 & 1.933 .761 \\
\hline & Q3 & 3.547 .897 & 2.986 .146 & 2.986 .146 & 1,18812 & 1.551 .732 & 2,28641 & 15 & 1,23419 & 1.915 .128 \\
\hline & $\mathrm{Q} 4$ & 3.075 .682 & 3.109 .947 & 3.109 .947 & 0,98898 & 1.566 .968 & 1,96282 & 16 & 1,22041 & 1.912 .345 \\
\hline \multirow{4}{*}{2009} & Q1 & 3.008 .861 & 3.141 .673 & 3.141 .673 & 0,95773 & 1.566 .742 & 1,92046 & 17 & 1,20664 & 1.890 .487 \\
\hline & $\mathrm{Q} 2$ & 2.934 .251 & 3.007 .021 & 3.007 .021 & 0,97580 & 1.549 .535 & 1,89363 & 18 & 1,19286 & 1.848 .378 \\
\hline & $\mathrm{Q} 3$ & 3.009 .291 & 3.195 .431 & 3.195 .431 & 0,94175 & 1.551 .732 & 1,93931 & 19 & 1,17908 & 1.829 .623 \\
\hline & $\mathrm{Q} 4$ & 3.829 .322 & 3.075 .955 & 3.075 .955 & 1,24492 & 1.566 .968 & 2,44378 & 20 & 1,16531 & 1.826 .001 \\
\hline \multirow{4}{*}{2010} & Q1 & 2.530 .955 & 3.045 .222 & 3.045 .222 & 0,83112 & 1.566 .742 & 1,61543 & 21 & 1,15153 & 1.804 .155 \\
\hline & $\mathrm{Q} 2$ & 2.811 .318 & 2.883 .071 & 2.883 .071 & 0,97511 & 1.549 .535 & 1,81430 & 22 & 1,13776 & 1.762 .994 \\
\hline & $\mathrm{Q} 3$ & 2.360 .689 & 2.794 .255 & 2.794 .255 & 0,84484 & 1.551 .732 & 1,52132 & 23 & 1,12398 & 1.744 .118 \\
\hline & Q4 & 3.474 .057 & 2.660 .318 & 2.660 .318 & 1,30588 & 1.566 .968 & 2,21706 & 24 & 1,11021 & 1.739 .657 \\
\hline \multirow{4}{*}{2011} & $\mathrm{Q} 1$ & 1.995 .208 & 2.693 .946 & 2.693 .946 & 0,74063 & 1.566 .742 & 1,27348 & 25 & 1,09643 & 1.717 .823 \\
\hline & $\mathrm{Q} 2$ & 2.945 .830 & 2.602 .537 & 2.602 .537 & 1,13191 & 1.549 .535 & 1,90111 & 26 & 1,08265 & 1.677 .610 \\
\hline & $\mathrm{Q} 3$ & 1.995 .053 & 2.115 .718 & 2.115 .718 & 0,94297 & 1.551 .732 & 1,28569 & 27 & 1,06888 & 1.658 .613 \\
\hline & $\mathrm{Q} 4$ & 1.526 .780 & 1.939 .433 & 1.939 .433 & 0,78723 & 1.566 .968 & 0,97435 & 28 & 1,05510 & 1.653 .312 \\
\hline \multirow{4}{*}{2012} & Q1 & 1.290 .070 & 1.524 .541 & 1.524 .541 & 0,84620 & 1.566 .742 & 0,82341 & 29 & 1,04133 & 1.631 .491 \\
\hline & $\mathrm{Q} 2$ & 1.286 .262 & 1.525 .339 & 1.525 .339 & 0,84326 & 1.549 .535 & 0,83010 & 30 & 1,02755 & 1.592 .226 \\
\hline & $\mathrm{Q3}$ & 1.998 .245 & 1.851 .357 & 1.851 .357 & 1,07934 & 1.551 .732 & 1,28775 & 31 & 1,01378 & 1.573 .109 \\
\hline & $\mathrm{Q} 4$ & 2.830 .850 & 2.016 .131 & 2.016 .131 & 1,40410 & 1.566 .968 & 1,80658 & 32 & 1,00000 & 1.566 .968 \\
\hline \multirow{4}{*}{2013} & Q1 & 1.949 .166 & 2.065 .046 & 2.065 .046 & 0,94388 & 1.566 .742 & 1,24409 & 33 & 0,98622 & 1.545 .159 \\
\hline & $\mathrm{Q} 2$ & 1.481 .924 & 1.841 .909 & 1.841 .909 & 0,80456 & 1.549 .535 & 0,95637 & 34 & 0,97245 & 1.506 .843 \\
\hline & $\mathrm{Q} 3$ & 1.105 .695 & 1.439 .541 & 1.439 .541 & 0,76809 & 1.551 .732 & 0,71256 & 35 & 0,95867 & 1.487 .604 \\
\hline & $\mathrm{Q} 4$ & 1.221 .380 & 1.256 .768 & 1.256 .768 & 0,97184 & 1.566 .968 & 0,77945 & 36 & 0,94490 & 1.480 .623 \\
\hline & $\mathrm{Q} 1$ & 1.218 .072 & 1.222 .205 & 1.222 .205 & 0,99662 & 1.566 .742 & 0,77746 & 37 & 0,93112 & 1.458 .827 \\
\hline & $\mathrm{Q} 2$ & 1.343 .672 & 1.272 .719 & 1.272 .719 & 1,05575 & 1.549 .535 & 0,86715 & 38 & 0,91735 & 1.421 .459 \\
\hline 2014 & $\mathrm{Q} 3$ & 1.307 .750 & 1.312 .605 & 1.312 .605 & 0,99630 & 1.551 .732 & 0,84277 & 39 & 0,90357 & 1.402 .099 \\
\hline & $\mathrm{Q} 4$ & 1.380 .925 & 1.270 .155 & 1.270 .155 & 1,08721 & 1.566 .968 & 0,88127 & 40 & 0,88979 & 1.394 .279 \\
\hline & Q1 & 1.048 .271 & 1.225 .240 & 1.225 .240 & 0,85556 & 1.566 .742 & 0,66908 & 41 & 0,87602 & 1.372 .495 \\
\hline & $\mathrm{Q} 2$ & 1.164 .013 & 1.225 .798 & 1.225 .798 & 0,94960 & 1.549 .535 & 0,75120 & 42 & 0,86224 & 1.336 .075 \\
\hline 2015 & $\mathrm{Q} 3$ & 1.309 .983 & 1.225 .753 & 1.225 .753 & 1,06872 & 1.551 .732 & 0,84421 & 43 & 0,84847 & 1.316 .594 \\
\hline & $\mathrm{Q} 4$ & 1.380 .746 & 1.246 .973 & 1.246 .973 & 1,10728 & 1.566 .968 & 0,88116 & 44 & 0,83469 & 1.307 .935 \\
\hline & Q1 & 1.133 .148 & 1.295 .585 & 1.295 .585 & 0,87462 & 1.566 .742 & 0,72325 & 45 & 0,82092 & 1.286 .163 \\
\hline & $\mathrm{Q} 2$ & 1.358 .464 & 1.317 .813 & 1.317 .813 & 1,03085 & 1.549 .535 & 0,87669 & 46 & 0,80714 & 1.250 .691 \\
\hline 2016 & $\mathrm{Q} 3$ & 1.398 .894 & 1.353 .859 & 1.353 .859 & 1,03326 & 1.551 .732 & 0,90150 & 47 & $\begin{array}{l}0,79336 \\
\end{array}$ & 1.231 .089 \\
\hline & $\mathrm{Q} 4$ & 1.524 .930 & 1.401 .350 & 1.401 .350 & 1,08819 & 1.566 .968 & 0,97317 & 48 & 0,77959 & 1.221 .590 \\
\hline & Q1 & 1.323 .111 & 1.397 .441 & 1.397 .441 & 0,94681 & 1.566 .742 & 0,84450 & 49 & 0,76581 & 1.199 .831 \\
\hline & $\mathrm{Q} 2$ & 1.342 .830 & 1.326 .664 & 1.326 .664 & 1,01219 & 1.549 .535 & 0,86660 & 50 & 0,75204 & 1.165 .308 \\
\hline 2017 & $\mathrm{Q} 3$ & 1.115 .784 & 1.243 .292 & 1.243 .292 & 0,89744 & 1.551 .732 & 0,71906 & 51 & 0,73826 & 1.145 .584 \\
\hline & $\mathrm{Q} 4$ & 1.191 .442 & 1.120 .095 & 1.120 .095 & 1,06370 & 1.566 .968 & $\begin{array}{l}0,76035 \\
\end{array}$ & 52 & 0,72449 & 1.135 .246 \\
\hline & Q1 & 830.323 & 956.509 & 956.509 & 0,86808 & 1.566 .742 & 0,52997 & 53 & 0,71071 & 1.113 .499 \\
\hline & $\mathrm{Q} 2$ & 688.486 & 852.048 & 852.048 & 0,80804 & 1.549 .535 & 0,44432 & 54 & 0,69693 & 1.079 .924 \\
\hline 2018 & Q3 & 697.941 & 750.260 & 750.260 & 0,93027 & 1.551 .732 & 0,44978 & 55 & 0,68316 & 1.060 .079 \\
\hline & $\mathrm{Q} 4$ & 784.291 & 699.330 & 699.330 & 1,12149 & 1.566 .968 & 0,50052 & 56 & $\begin{array}{l}0,66938 \\
\end{array}$ & 1.048 .902 \\
\hline & Q1 & 626.602 & 658.830 & 658.830 & 0,95108 & 1.566 .742 & 0,39994 & 57 & 0,65561 & 1.027 .167 \\
\hline 2019 & $\mathrm{Q} 2$ & 526.487 & 597.850 & 597.850 & 0,88063 & 1.549 .535 & 0,33977 & 58 & 0,64183 & 994.540 \\
\hline 2019 & $\mathrm{Q} 3$ & 454.021 & 519.371 & 519.371 & 0,87417 & 1.551 .732 & 0,29259 & 59 & 0,62806 & 974.575 \\
\hline & $\mathrm{Q} 4$ & 470.374 & 443.613 & 443.613 & 1,06032 & 1.566 .968 & 0,30018 & 60 & 0,61428 & 962.557 \\
\hline & Q1 & 323.571 & 348.117 & 348.117 & 0,92949 & 1.566 .742 & 0,20652 & 61 & 0,60050 & 940.836 \\
\hline & $\mathrm{Q} 2$ & 144.500 & 282.424 & & & 1.549 .535 & 0,09325 & 62 & 0,58673 & 909.157 \\
\hline 2020 & Q3 & 191.250 & & & & 1.551 .732 & 0,12325 & 63 & 0,57295 & 889.070 \\
\hline & Q4 & & & & & 1.566 .968 & & 64 & 0,55918 & 876.213 \\
\hline & Q1 & & & & & 1.566 .742 & & 65 & 0,54540 & 854.504 \\
\hline & $\mathrm{Q} 2$ & & & & & 1.549 .535 & & 66 & 0,53163 & 823.773 \\
\hline 2021 & $\mathrm{Q} 3$ & & & & & 1.551 .732 & & 67 & 0,51785 & 803.565 \\
\hline & Q4 & & & & & 1.566 .968 & & 68 & 0,50407 & 789.869 \\
\hline
\end{tabular}

Fig. 2. Forecasting result. 


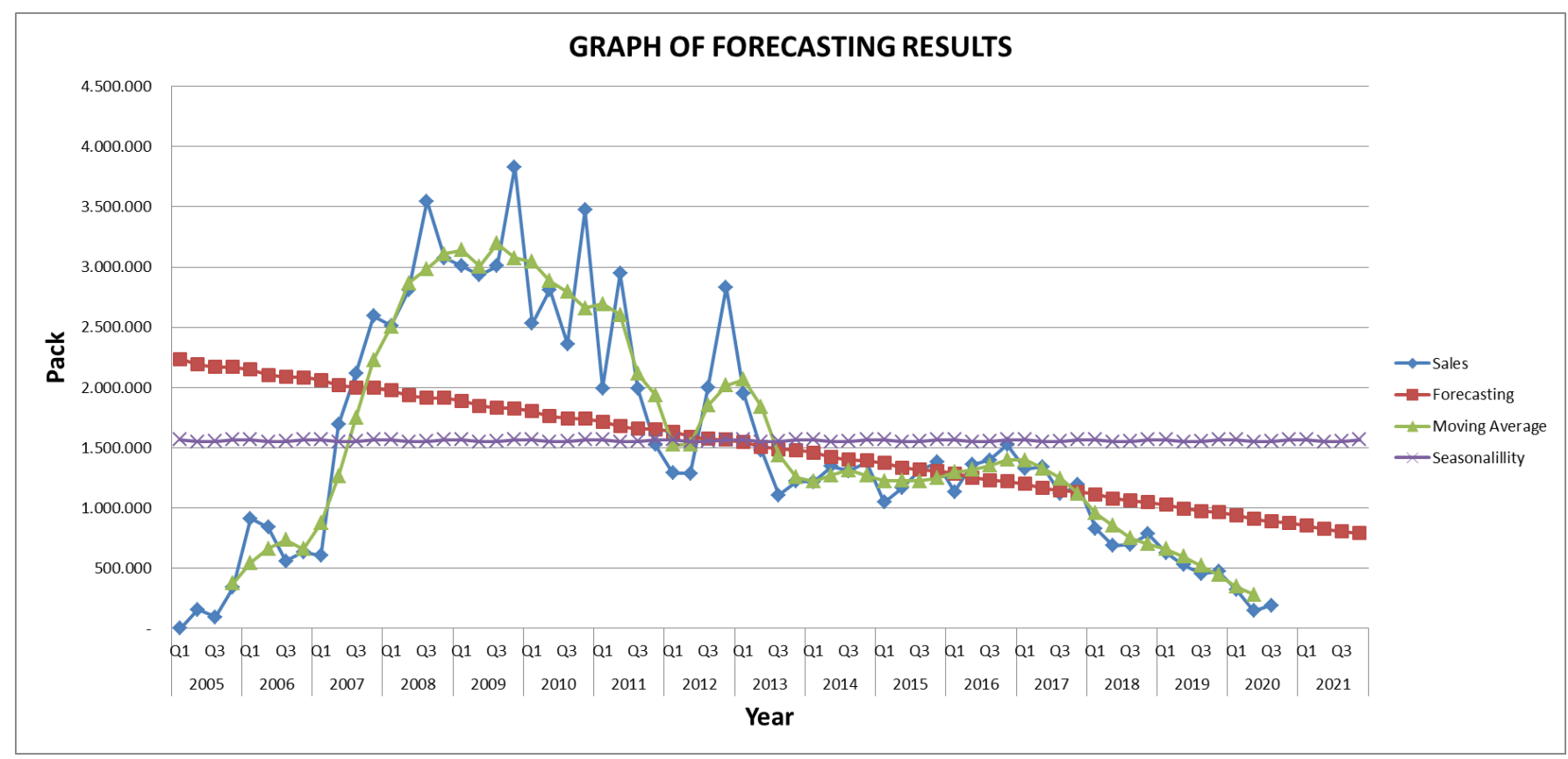

Fig. 3. Graph of forecasting results.

To find out the moving average formula's function, use one of the Excel application tools, namely regression, in the data analysis tools. The regression calculation is based on the moving average data, in which the seasonal factor $t$ is the period. The results of regression calculations are shown in table 2. For forecasting, results are calculated using a formula based on the regression results by calculating Seasonality multiplied by trend. The results for forecasting calculations and forecasting charts are shown in figure 2 and figure 3.

Figure 2 for forecasting calculations show that for 2021, cigarette sales after the pandemic could experience an increase in sales. Although, in general, the forecasting trend is decreasing, when compared to actual sales, the forecasting results for sales have increased. This means that based on past data, this company can increase sales in 2021.

Based on figure 3, the graph shows that the forecasting trend has consistently decreased from 2005, while actual cigarette sales have shown a downward trend starting from 2016. This is due to many competitors with illegal products without excise stamps at much lower prices. Several other influencing factors were the increase in excise rates and a vat of tobacco products, with the selling price of cigarettes at the company not experiencing a growth, thus making the company experiencing difficulties in realizing the purchase of excise stamps.

\section{CONCLUSION}

The results of forecasting calculations cannot be used as a measure of sales in 2021. However, forecasting results can set sales targets in 2021 by considering other company's external and internal factors. Suggestions for further research are for forecasting in 2021 it is better to do it again with additional data for quarter 4 of 2020 and quarter 1 of 2021 because on December 15, 2020, there was a Minister of Finance Regulation (PMK) of the Ministry of Finance regarding an increase in tobacco product excise ribbon rates for 2021. This PMK has a significant effect. Significant for companies looking to stabilize sales after a pandemic. Companies' suggestion is to cooperate with the Customs and Excise Office to eradicate illegal cigarettes that are competitors to the company. The marketing department also needs promotional programs to attract customers back.

\section{REFERENCES}

[1] Berita Lima, "Sindikat Pengedar Rokok Tanpa Cukai Ditangkap Polisi," [online]. Retrieved from https://beritalima.com/sindikat-pengedar-rokoktanpa-cukai-diciduk-polisi/

[2] A. Nurlifa and S. Kusumadewi, "Sistem Peramalan Jumlah Penjualan Menggunakan Metode Moving Average Pada Rumah Jilbab Zaky," INOVTEK Polbeng - Seri Inform, vol. 2, no. 1, p. 18, 2017.

[3] K. Khamaludin, "Peramalan Penjualan Hijab Sxproject Menggunakan Metode Moving Average Dan Exponential Smoothing," Unistek, vol. 6, no. 2, pp. 13-6, 2019.

[4] N. Sulthan, N. Eltivia, and N.I. Riwajanti, "Implementasi Metode Exponential Smoothing Untuk Peramalan Kedatangan Wisatawan Mancanegara Pada Pulau Bali," Media Mahard, 2020.

[5] B. Setyawan, N.I. Riwajanti, and S. Ismanu, "Analisis Peramalan Menggunakan Arima Pada Indeks Harga Perdagangan Besar Indonesia Kelompok Komoditi Pertanian Tahun 2000-2019," Media Mahard, 2020 . 
[6] S. Ramnath, S. Rock, and P. Shane, "The financial analyst forecasting literature: A taxonomy with suggestions for further research," Int J Forecast, 2008.

[7] K. Azaro, N.I. Riwajanti, and A. Kusmintarti, "Triple Exponential Smoothing: Forecasting Perbandingan Penumpang Kereta Api Dan Pesawat Terbang," Media Mahard, 2020.

[8] Riduwan, Metode dan Teknik Menyusun Skrisi dan Tesis. Bandung: Alfabeta, 2015

[9] J.S. Armstrong and D.M. Georgoff, "Harvard Business Review," Int J Forecast, 1988.

[10] T. Hong and S. Fan, "Probabilistic electric load forecasting: A tutorial review," Int J Forecast, 2016.

[11] A. Timmermann and C.W.J. Granger, "Efficient market hypothesis and forecasting," Int J Forecast, 2004.

[12] J.G. De Gooijer and R.J. Hyndman, "25 years of time series forecasting. Int J Forecast," 2006;

[13] G. Zhang, B. Eddy Patuwo, M.Y. Hu, "Forecasting with artificial neural networks: The state of the art," Int J Forecast, 1998.
[14] N. Meade and T. Islam, "Modelling and forecasting the diffusion of innovation - A 25-year review," Int J Forecast, 2006.

[15] E.S. Gardner, "Exponential smoothing: The state of the art-Part II," Int J Forecast, 2006.

[16] R.J. Hyndman and A.B. Koehler, "Another look at measures of forecast accuracy," Int J Forecast, 2006.

[17] F. Collopy, “Journal of economic psychology,” Int J Forecast, 1995.

[18] J. Supranto, No Title. 7th ed. Jakarta: Fakultas Ekonomi Universitas Indonnesia, 2003

[19] B.I. Swastha, Manajemen Pemasaran Modern. Yogyakarta: Liberty, 2014.

[20] S. Makridakis, C.S. Wheelwright, and V.E. McGee, Metode dan Aplikasi Peramalan Edisi Kedua. Erlangga, 2000.

[21] B.P. Prasetya, "Penerapan Metode Single Moving Average (SMA) pada Aplikasi Peramalan Penjualan Di Kedai Digital \#24 Kediri," [Online]. Retrieved from simki.unpkediri.ac.id 